\title{
Analysis of Custom Education in Zhou Li
}

\author{
Qi Dandan \\ Institute of Business \& Economic Reasearch , \\ Harbin University of Commerce,Harbin,Heilongjiang Province, China \\ qidandan77777@126.com
}

\begin{abstract}
Zhou Li records many folk activities and folk rules and brings forward three concepts of custom, traditional custom and etiquette custom. This paper firstly presents a systematic differentiation of etiquette, custom, etiquette custom, and traditional custom according to the content as well as its commentaries of $\mathrm{Zhou} L i$ and then analyzes its specific contents and functions of the customs recorded in Zhou Li. At last, the paper makes a comparative study of custom education between the Qin state and $\mathrm{Zhou} \mathrm{Li}$. Then it concludes that the custom education recorded in $\mathrm{Zhou} \mathrm{Li}$ is implemented by the chancellor and his subordinate officers, of which the whole process is completed in an imperceptible permeation. While the Qin state plays hardball to carry out custom education and enforces it nationwide by resorting to laws.
\end{abstract}

Keywords-Zhou Li; etiquette custom; traditional custom; education

Zhou Li lays much emphasis on educating the common people about customs. The sixth content of the twelve educations taken charge by the chancellor is: educate people to settle down so that they won't drift along. Zheng Xuan holds that "custom" is a habit coming out of the ground. Receiving custom education, people can feel the joy of growth and reproduction as well as the happiness of kinship and they won't drift along with such a mood. Now let's take a first investigation of the content of custom education.

\section{CONTENTS OF "EDUCATING PEOPLE TO SETTLE DOWN WITH CUSTOMS"}

\section{A. Research on the "six traditional customs"}

It's mentioned in Zhou Li-Tai Situ to "settle down people by six traditional customs", stressing the importance of educating people with customs. The six traditional customs refer to: a) build solid houses; b) distribute graves according to the clans; c) unite brothers of different surnames; d) unite juniors in the village to study from teachers; e) unite friends; f) unify people's clothes. The chancellor not only teaches people how to deal with funerals appropriately but also proposes various clans to form a team and develop mutual aid spirit to help each other dealing with funerals, thus developing a feeling of dependent life and death among the clan.

Zhou Li tries to unite people together by such ethical relations as clan, marriage, teacher-student, friends, etc. Yi $\mathrm{Fu}$ from the Southern Song Dynasty considers that being content with traditional customs makes people kind and simple1. Custom education can enhance people's sense of identity in customs and make people live in harmony and share adversity. "Traditional customs" epitomize the concepts of sticking to convention and "following the customs". The system in Zhou Li is established from the national level to observe traditional rules without changes within a specific space-time range, which is the so-called adherence of its traditional customs. Respect for customs is the basis of Zhou Li's governing and is also an effective measure of solving different customs. The concept and ideology of "traditional custom" in Zhou Li is succeeded and developed by later generations.

Tai Situ has the obligation to educate people to settle down with customs. It can be coordinated with the policies of "restricting the people with etiquettes and customs" to administrate the capital, which is taken charge by the prime minister. They both educate the people to follow rites through a series of folk activities and deepen their friendly contacts and good virtues by uniting brothers, teachers, friends and unifying clothes, thus developing an atmosphere of harmonious family, friendly neighborhood and good manners. To civilize the people and make them form good customs, Zhou Li should deepen into people's life through custom education and make their life customs conform to the rites. The chancellor carries out the custom education by implementing twelve educations, coordinating with the contents of virtue, act and art, performing the education mode of settling down people with traditional customs as well as putting into practice of etiquette education through the eight penalties.

Wang Zhichang in Ming dynasty thinks that every place forms certain customs according to its different ethos and this kind of customs possess permanency and is not easy to change ${ }^{2}$. It's mentioned in $\mathrm{Li} \mathrm{Ji}$.Wang Zhi that the system in deep mountains and remote areas is different and their customs are also quite different from the outside world. Therefore, Liu Qingzhi from Qing dynasty considers that customs are different due to various conditions and atmospheres. Transforming customs through the change of conditions is to suit the education in accordance with its differences ${ }^{3}$.

Tai Situ chooses suitable people and things according to five different terrains which form different lives and customs. Only implementing twelve educations according to the variations can unify virtues and customs and make people be bound by social customs. It's recorded in Zhou $\mathrm{Li}$ that those titles from "Zai Shi" to "Jun Ren" are all in charge of issues about territory and people and titles from "Shi Shi" to "Mei Shi" are all in charge of educating people about various prohibitions. Guan $\mathrm{Zi}$ ever said: "that hidden in the government is law and that implemented across the country is custom". In order to be one-minded and united nationwide, heresies must be banned and bad customs must be removed. Royal court needs basic ministers, a country needs basic customs and the people need basic industries. Changing a country's 
fixed customs out of self-will is disobeying the administrator. And customs have family custom, nation custom and even the world custom. Though countries may differ in size or distance, they all have their own ancestor disciplines and rules. When the later generations give up these disciplines, they will be accused of forgetting their own origin or undermining family rules.

\section{B. Etiquette custom--- "control the people"}

"Etiquette custom" plays an important role in administering state affairs well and ensuring national security. The Prime Minster in Zhou Li stipulates to govern fiefdoms around the capital with eight systems. And the sixth one indicates that etiquette custom is to bind the people. Among the eight systems taken charge by the prime minister, etiquette together with sacrifice, law, abandonment, office rank, taxation and tribute, reward and penalty and field service all jointly contribute to administering the capital and fiefdoms.

Jia Gongyan takes the etiquette custom as a rite of marriage. In ancient times, the followed actions are always called customs and it's to "control the people" by making people act in accordance with such customs and do good things. The function of etiquette here is to edify the people in the capital and fiefdoms. Zhou Li.Di Guan.Tu Jun announces various kingdoms' government decrees, criminal laws, prohibitions and rules of removing taxes and corvees. It also declares that etiquette, funeral and sacrifice are all executed according to the land quality. Zheng Xuan ${ }^{4}$ ever said: "etiquette is the old ritual left by former kings and is to be followed by the people". Men of noble characters follow the etiquettes instead of changing customs and formulate policies according to the local land quality. Custom is continuous according to Zheng Xuan". He cited a phrase in $Q u L i$ to prove it: "a gentleman performs etiquettes instead of changing customs" and stated that the Duke of Zhou conferred Kang Shu Fang to Yin Ruin and made his people keep the customs and etiquettes of Yin Dynasty. "Etiquette" has its basic principles in the process of practice and practicing "etiquette" in accordance with the actual situations is to adjust measures to local conditions.

Autumn officers record different information in books including five parts: all the favorable and adverse influences that natural environments exert on the people; whether each kingdom can follow its etiquettes, politics, education administration, penalties and prohibitions; each kingdom's riots, evils and breach of prohibitions; each kingdom's plagues, funerals and famines; each kingdom's health, recreation and peace. The officers conclude the five parts in five books and report them to the king, who then knows all the news of different regions. Jia Gongyan thinks that the autumn officers' action of traveling around all kingdoms, recording good and bad customs and then concluding books to report to the king follows the principle of diversity and is a kind of inheritance of etiquette $^{6}$.

Zheng Xuan elaborates the relation among "etiquette", "custom" and "etiquette custom". He views the meaning of "etiquette" and "custom" to be the same in Tu Jun and Xiao Xing Ren ${ }^{7}$. Sun Yi raises an objection to Zheng Xuan's understanding and thinks that etiquette and custom is quite different. Etiquette means a rite of good or ill luck. For example, the chancellor applies Yang etiquette of the twelve educations to educate people to be humble and Yin etiquette to educate people to be friendly. While custom is born from the ground and is different from etiquette, it needs continuous transformation. Huang $\mathrm{Du}$ from Song dynasty thinks that the property tax governed by Tu Jun should be in accordance with local customs and be measured according to the criteria of etiquettes ${ }^{8}$. We agree with Sun $\mathrm{Yi}^{9}$.

\section{Traditional custom and local custom---to stabilize the people}

Besides "etiquette custom", Zhou Li also puts forwards the concept of "traditional custom". "Stabilize the people with custom education" is an important factor of settling down the people and making them edified. "Tau Situ" is in charge of "implementing twelve educations according to the different customs formed in the five terrains' outgrowth. And the first step is to educate people to be humble with Yang etiquette......the sixth is to settle down the people with customs so that they will not drift along". Zheng Xuan explained: "custom means that people's living environments are different and the people won't be stabilized if traditional customs are changed" $"$. People will settle down and live in peace instead of drifting along with customs education. Zhou $\mathrm{Li}$ 's respect for folk customs is not only embodied in advocating the "traditional custom" but also reflected in the concept of "local custom". Terrestrial officers are responsible for narrating the history allusions of different regions and reporting them to the king. They also take in charge of explaining the language taboos of diverse regions to avoid the king from offending the taboos and making him know about different regions' customs and habits. Zheng Xuan considers that "Fang Te" refers to the taboos of different regions and having a good knowledge of local customs will make them cautious of languages and conform to the local customs. Zheng Sinong ever said: "one should be aware of the taboos stipulated in the imperial edict and can't go against the local customs". Jia Gongyan said: "the terrestrial officers take in charge of taboos of different regions and let the king know about the local customs and language conditions". Zheng Xuan cited the phrase "a gentleman performs etiquettes instead of changing customs" in Zhou $\mathrm{Li} \cdot \mathrm{Qu} \mathrm{Li}$ explaining "language taboos of different regions" and "geographical customs" as well as Tu Jun. It's mentioned at first that old customs of former kings are etiquettes and can't be changed. Later it's also mentioned that the local taboos can't be changed. They both stress on "not changing customs" though they have their own connotations.

In conclusion, the concepts of "traditional custom" and "local custom" mentioned in Zhou Li are consistent with its promotions of following and respecting folk customs.

From the above analysis, we can at least conclude two points. Firstly, custom is related with the people from its origin. Secondly, "etiquette custom", "etiquette" and "custom" are closely related, but "custom" is different from "etiquette". It's universally acknowledged in the academic field that etiquette derives from custom. "Etiquette" emerges from the womb of "custom" and is the standardization and institutionalization of custom. We hold such opinion that etiquette and custom are parallel in actual practices ${ }^{11}$. Zhou $\mathrm{Li}$ has no specific contents and 
forms of "etiquette customs". But it can be conjectured from its application that "etiquette" had had its specific connotation when the book was compiled. The people at that time had been quite familiar with this concept, so they didn't need detailed explanations. Zhou Li also brings forward that the function of etiquette custom is to control the people. In a sense, settling down the people with customs is a method of "controlling the people".

\section{OBJECTIVES AND CHARACTERISTICS OF CUSTOM EDUCATION}

Both Zhou $\mathrm{Li}$ and $\mathrm{Li} \mathrm{Ji}$ emphasize the importance of customs education on people. The chancellor of Rites of the Zhou educates people with customs. $\mathrm{Li} J \mathrm{~J}$. Xue Ji puts forward that it must be started from education to cultivate the people to form good customs. The objective of educating people with customs is to cultivate the people to from good customs. Yan $\mathrm{Zi}$ considers that the custom of sincere and honest people is the foundation of a benevolent government and governors can only make the people know laws and unify customs through education. In his opinion, the key point of preventing a country's destruction is conducting education of unifying customs $^{12}$.

Discussed above for the "local custom", it can be known that "local custom" embodies the spirit of mutual aid. According to Rites of the Zhou, the spirit of custom education can be reflected in basic level education and the local executive officers of each level undertake the responsibility of edifying people with customs.

The executive organization mode recorded in $\mathrm{Di}$ Guan.Tai Situ and Sui Ren is as following:

Of all the organizations, "family" is the smallest organization unit. Six villages nearby are marshaled and five families are organized as a team, which they can depend on each other when they need help. If one family commits a crime, the other four families would be involved. In this way, they can supervise one another among the five families. Five teams can be organized to be a bigger unit "neighborhood" so that they can care about each other. Four "neighborhoods" can be organized to a unit "clan" and five "clans" to be a "party", then five "parties" to a district. And five "districts" constitute a "village", in which they respect those people with noble characters and outstanding talents. This method goes the same way for Sui. Five families make up a Lin, five Lin a $\mathrm{Li}$, four $\mathrm{Li}$ a Zan, five Zan a Bi, five Bi a county and then five counties constitute a Sui. Each organization has its own areas and they dig ditches and plant tress to mark in the dividing lines. As regard to the establishment, it keeps the same to both village and Sui. They just differ at names.

Zhou Li appraises "clan grave" as a very good custom. The people from the same clan live together when alive and it's derived that they should be also buried together when they are dead. It's a tradition preserved due to the existed blood relationship. Five families have close blood relationship as the basic unit and they keep close relations. They supervise and promise each other not to commit crimes and express condolences to each other during funerals. This kind of regulation makes people bear various restrictions and they can hardly move a step without authenticity documents. Therefore, every family as well as everyone is under strict control and is firmly bound to the land.

This set of social organization and public education method designed in Zhou Li mainly has two functions. On one hand, it's reflected in the part of economics as it makes people attached to the land and focus on productive labor. The objective of this method is to enable the people attached to the land to offer governors production results. On the other hand, this compact organization is of military significance. The organization of six villages and six Sui is actually a kind of military organization. The people do farm work in peacetime and they can be organized as armies in war times. It's recorded in Rites of the Zhou that the head officer of village and Sui as well as its subordinate officers supervises people to do farm work in peacetime and becomes military officer to lead the people to fight in war times. In a word, Zhou Li implements custom education to the people and tries to make people peaceful, reflecting the mutual aid spirit and possessing the characteristics of clan-gathering and solidarity.

This paper makes a comparative analysis of traditional custom, etiquette custom and local custom recorded in Zhou $\mathrm{Li}$ and concludes the objectives and characteristics of custom education. It also makes a comparative study of custom education between the Qin state and Zhou Li and concludes that their custom educations are two distinct education modes. The custom education recorded in Zhou $\mathrm{Li}$ is conventionalized. It is implemented by the chancellor and his subordinate officers, of which the whole process is completed in an imperceptible permeation. While the Qin state plays hardball to carry out custom education and enforces it nationwide by resorting to laws.

\section{ACKNOWLEDGEMENTS}

This work is supported by $\mathrm{PhD}$ research startup project of Harbin University of commerce.Item Nmuber:15RW23.

\section{REFERENCE}

[1] [Qing Dynasty] revised by Yun Lu,etc: Commentary of authorized officers of the Zhou, volume nine, photography of Complete Library in the Four Branches of Literature

[2]Wang Zhichang: Abridged Commentary of Rites of the Zhou, volume seven, photography of Complete Library in the Four Branches of Literature

[3][Qing Dynasty]Liu Qingzhi: Question to Rites of the Zhou, editorial committee of Continuation of the Four Branches of Literature: Continuation of the Four Branches of Literature, Shanghai Ancient Books Publishing House, 2002, volume 79, page 451

[4][Qing Dynasty]Sun Yirang: A summary of Zhou justice, Publishing House of China, 1987, page 1179

[5][Qing Dynasty]Sun Yirang: A Summary of Zhou Justice, Publishing House of China, 1987, page 1180

[6]Annotated by Zheng Xuan, interpreted by Jia Gongyan: Commentary of Rites of the Zhou calibrated by Ruanyuan Commentary of Thirteen Classics, photography of Shanghai Ancient Books Publishing House, 1997, page 894

[7][Qing Dynasty]Sun Yirang: A Summary of Zhou Justice, Publishing House of China, 1987, page 1180

[8][Qing Dynasty] Sun Yirang: A Summary of Zhou Justice, Publishing House of China, 1987, page 67

[9][Song Dynasty]Huang Du: [Qing Dynasty] proofread and edited by Chen Jin: Views of Rites of the Zhou, editorial committee of Continuation of the Four Branches of Literature: Continuation of the Four Branches of Literature, Shanghai Ancient Books 
Publishing House, 2002, volume 78, page 7

[10][Qing Dynasty]Sun Yirang: A Summary of Zhou Justice, Publishing House of China, 1987, page 705

[11]Zhang Zichen: Chinese History of Folklore (early folk records and etiquette views in the second chapter), Jilin Literature and History Press, 1993, page 37

[12]Wu Zeyu: Yanzi Annotation, Publishing House of China, 1982, page 221 